\title{
Satiating the demand: Planning for alternative models of regional food distribution
}

\author{
Lindsey Day-Farnsworth ${ }^{\mathrm{a}}$ and Alfonso Morales, ${ }^{\mathrm{a}, *}$ University of Wisconsin
}

Submitted 7 April 2011 / Accepted 19 October 2011 / Published online 29 December 2011

Citation: Day-Farnsworth, L., \& Morales, A. (2011). Satiating the demand: Planning for alternative models of regional food

distribution. Journal of Agriculture, Food Systems, and Community Development. Advance online publication.

http://dx.doi.org/10.5304/jafscd.2011.021.020

Copyright (C 2011 by New Leaf Associates, Inc.

\begin{abstract}
Despite the relative absence of wholesale distribution in much of the planning profession's academic and grey literature, emerging models promise to remake the relationship between producers and their regional markets. In this article, key lessons from the value(s) chain literature are illustrated with examples from comparative case studies conducted by the University of Wisconsin-Madison Center for Integrated Agricultural System to acquaint professional planners and allied professionals with strategies for imbuing mid- to highvolume local food distribution with normative values such as transparency and fairness. The research presented here is not a comprehensive
\end{abstract}

${ }^{a}$ University of Wisconsin - URPL, 925 Bascom Mall, 104 Music Hall, Madison, WI 53706 USA.

* Corresponding author: Alfonso Morales, +1-608-263-4848; morales1@,wisc.edu analysis of regional wholesale food distribution. Rather, we have focused on organizational, logisti$\mathrm{cal}$, and marketing characteristics of local and regional food value(s) chains. We utilize an exploratory comparative case study method to identify innovations in food distribution focusing on midtier food value(s) chains. We then describe larger system interventions that planners could employ to better accommodate midtier food distribution needs in the regional planning and food regulatory environment. These interventions include documentation of existing wholesale food system infrastructure; incorporation of agricultural industry clusters into regional economic development planning; cultivation of regional culinary identities to enhance marketing and branding efforts; and collaboration with policy makers and food safety regulators to foster zoning and regulation that protect public safety and welfare and 
build the capacity and market access of local food entrepreneurs.

\section{Keywords}

business models, food distribution, food system planning, food systems, value chains

\section{Introduction}

In June 2010 four professional associations, the American Dietetic Association, the American Nurses Association, the American Planning Association (APA), and the American Public Health Association, convened in order to develop a set of shared principles to orient practitioners and associations in their work transforming the food system. Following are the principles detailed in the resulting document, Principles of a Healthy Sustainable Food System (American Dietetic Association, the American Nurses Association, the American Planning Association, and the American Public Health Association, 2010):

- health-promoting

- sustainable

- resilient

- diverse in scale, geography, culture, and food choice

- fair for farmers, workers, and eaters

- economically balanced

- transparent

This set of principles, along with other professional pronouncements like the 2007 APA Policy Guide on Community and Regional Food Planning (American Planning Association, 2007), are substantial responses to rapidly increasing interest from many professional societies and policy makers for information and resources about how to build sustainable, community and regional food systems.

For at least a decade, urban and regional planners have worked to establish and advance these objectives in the food system by facilitating farmland conservation initiatives, promoting and streamlining permitting processes for farmers' markets, expanding urban agricultural activities through innovative zoning code revisions, and increasing community access to fresh food through super- market attraction initiatives and improved accommodation of Supplemental Nutrition Assistance Program (SNAP) (formerly food stamps) and Women, Infants and Children (WIC) supplemental food benefits at farmers' markets. Taken together, these advances have expanded farmers' access to local markets and consumers' access to fresh product. Still, noticeably absent from this list of accomplishments is planners' participation in supply chain development and high-volume distribution. Perhaps this absence is best explained by Pothukuchi and Kaufman's observation that many planners perceive the food system as being driven primarily by the private market (2000). This may be especially true for issues pertaining to supply chain coordination, which superficially appear further outside the purview of planning practitioners than issues pertaining to agricultural land use and household hunger.

Nevertheless, as local and regional food systems scale up to accommodate the growing demand for local food and bridge the gap between alternative and industrial food systems, food supply chains necessarily become more complex, and new knowledge is needed about how to incorporate normative values into supply chain dynamics. Toward this end, our thesis is that urban and regional planners and allied professionals could learn a great deal from food values(s) chains research and development about how to imbue principles such as scalar diversity, fairness, and transparency into the configuration of local and regional food distribution. In this article, we identify three critical components of midtier food value(s) chains - aggregation, transparency and source identity throughout the supply chain, and fair pricing practices - and discuss how they are expressed in three case studies produced by the University of Wisconsin-Center for Integrated Agriculture Systems (CIAS). The cases examined here are the Organic Valley Produce Program, Coop Partners Warehouse, and Growers' Collaborative. We close by proposing interventions that would help make planning processes and regulatory environments more supportive of the formation of food value(s) chains. 


\section{Defining Characteristics of Local Wholesale Food Value(s) Chains}

In this section we define food value(s) chains and identify three characteristics of local and regional food distribution models that show the greatest potential for integrating efficiency and equity across the local food supply chain. Stevenson and Pirog define midtier food value chains as "valuesbased strategic alliances between midsize independent (often cooperative) food production, processing, and distribution/sales enterprises that seek to create and retail more value on the front (farmer/rancher) end of the chain, and effectively operate at regional levels with significant volumes (Stevenson \& Pirog, n.d., p. 19)." "As follows, food value(s) chains are distinct from traditional food supply chains both because they attempt to distribute risk and profit more evenly across the supply chain, and because they differentiate their products in the marketplace on the basis of their social and environmental attributes. Here "midtier food value chains" is shortened to "food value(s) chains" rather than "value chain" to denote both the normative values they encompass and the incremental value added to agricultural products as they move from field to fork.

The food value(s) chain literature (Barham, 2008; Day-Farnsworth, McCown, Miller, \& Pfeiffer, 2009; Stevenson \& Pirog, 2009) has identified a range of critical issues pertaining to food value(s) chains, including concerns regarding collective action (Lev \& Stevenson, 2011), “adequate capitalization and competent management" (Stevenson, 2009 , p. 11), the "fair pricing dilemma" — the fact that "business models designed to help producers retain a larger percent of the retail food dollar typically operate at price points that make their products unaffordable to low-income markets" (DayFarnsworth, Bruner Zimmerman, \& Daniel, forthcoming), and under-representation of people of color in entrepreneurial and organizational leadership positions within alternative and local food systems (Morales, forthcoming). Food

\footnotetext{
${ }^{1}$ According to the USDA, U.S. consumer demand for locally grown foods could reach US $\$ 7$ billion by 2012 , nearly double the demand in 2002 (USDA, 2009).
}

value(s) chains face significant challenges in all of these regards, and each warrants further attention. However, here we choose to focus specifically on organizational, logistical, and marketing characteristics of local and regional food value(s) chains with two goals: (1) to acquaint planning practitioners with the critical components of midtier value(s) chains, and (2) to identify the considerations salient to the planning and regulatory interventions proposed at the conclusion of the article. Following are short explanations of the function and importance of aggregation, transparency and source identity, and fair pricing practices in regional food value(s) chains.

\section{Aggregation}

Aggregation is one of the first crucial post-harvest activities in many midvolume value chains. The University of Wisconsin Center for Integrated Agricultural Systems defines aggregation as "the consolidation of products sourced from multiple growers (Day-Farnsworth et al., 2009, p. i)."2 Product aggregation achieves one or both of the following goals: (1) to diversify the number of product offerings; and (2) to achieve large volumes of a single product. Distributors and/or groups of small and midsize growers aggregate product to compete with large growers in local and regional retail and institutional markets. In many instances, aggregation for wholesale markets is employed to increase volume and diversify product offerings.

Figure 1 illustrates distinct points along the fresh produce supply chain at which farm product is aggregated and sold. Aggregation Point 1 is characteristic of direct-marketing such as Community Supported Agriculture (CSAs) and farm stands (i.e. the farmer sells product directly to the end consumer). Farm identity is usually preserved at this transaction level. Aggregation Point 2 adds a "hub"

\footnotetext{
${ }^{2}$ With regard to these value chains, Stevenson and Pirog (n.d.) define "significant volumes" as those ranging between directmarketing and commodity system quantities, noting that levels will vary with geography, geographic identities, food products, and market demographics.
} 
Figure 1. Aggregation Points and Distribution Paths Across the Local/Regional Food Supply Chain

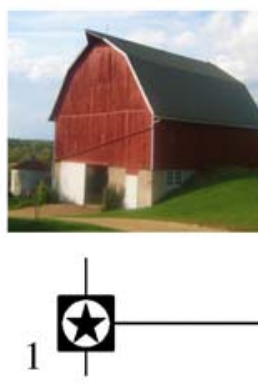

On-farm
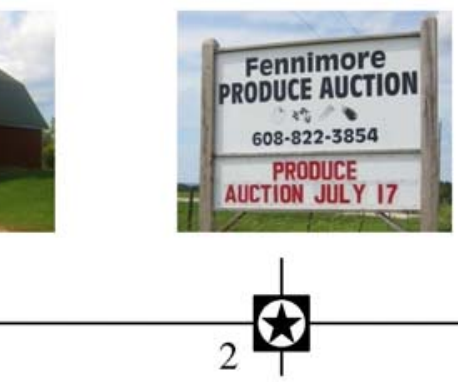

Off-farm hub

(physical or virtual)

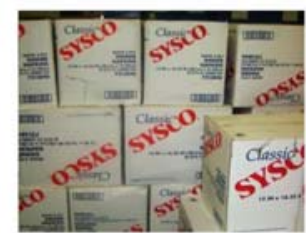

3

Broadline Distribution

Center

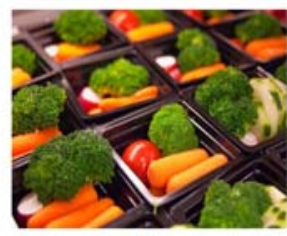

4

\section{Retail/Institutional food buyer}

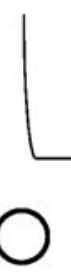

Aggregation point

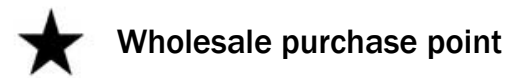

3PL

3PL

Packing point

Third Party Logistics (3PL) can be used to transport product between any combination of segments of the supply chain.

link to the supply chain to aggregate from many producers, thus diversifying product, increasing

volume, or both. Such aggregation may take the form of a physical structure such as a packhouse and produce auction, or it might manifest as a virtual hub where multiple farms' inventories are listed to enable one-stop-shopping for large volume buyers. At this aggregation point, farm product may retain farm identity, be branded by the aggregation entity, or both. Aggregation Point 3 extends the supply chain by introducing broadline distributors such as Sysco, which usually source through a combination of farm-direct transactions and off-farm hubs. Characteristic of industrial food distribution, farm identity is typically lost when broadline distributors administer aggregation. Aggregation Point 4 represents on-site aggregation by institutional and retail customers. Although this aggregation point may appeal to small growers accustomed to direct sales, wholesale buyers seek efficiency by substituting many suppliers, for fewer broadline distributors because of the diverse product lines and one-stop-shopping they provide (Day-

Farnsworth et al., 2009).

\section{Transparency and Source Identity}

The "Ten Reasons to Buy Local Food" list published by University of Vermont Extension (Grubinger, 2010) echoed the sentiments of many local food advocates in making the claim, "There's a unique kind of assurance that comes from looking a farmer in the eye at farmers' market or driving by the fields where your food comes from. Local farmers aren't anonymous and they take their responsibility to the consumer seriously." This statement captures an essential element of the local food movement: the consumers' desire to reconnect with their food.

A 2010 publication by the University of Wisconsin Center for Integrated Agricultural Systems depicts "The Tiers of the Food System" (see figure 2), a conceptual tool that illustrates how supply chain relationships change as scale (both volume and 


\section{Figure 2. The Tiers of the Food System}

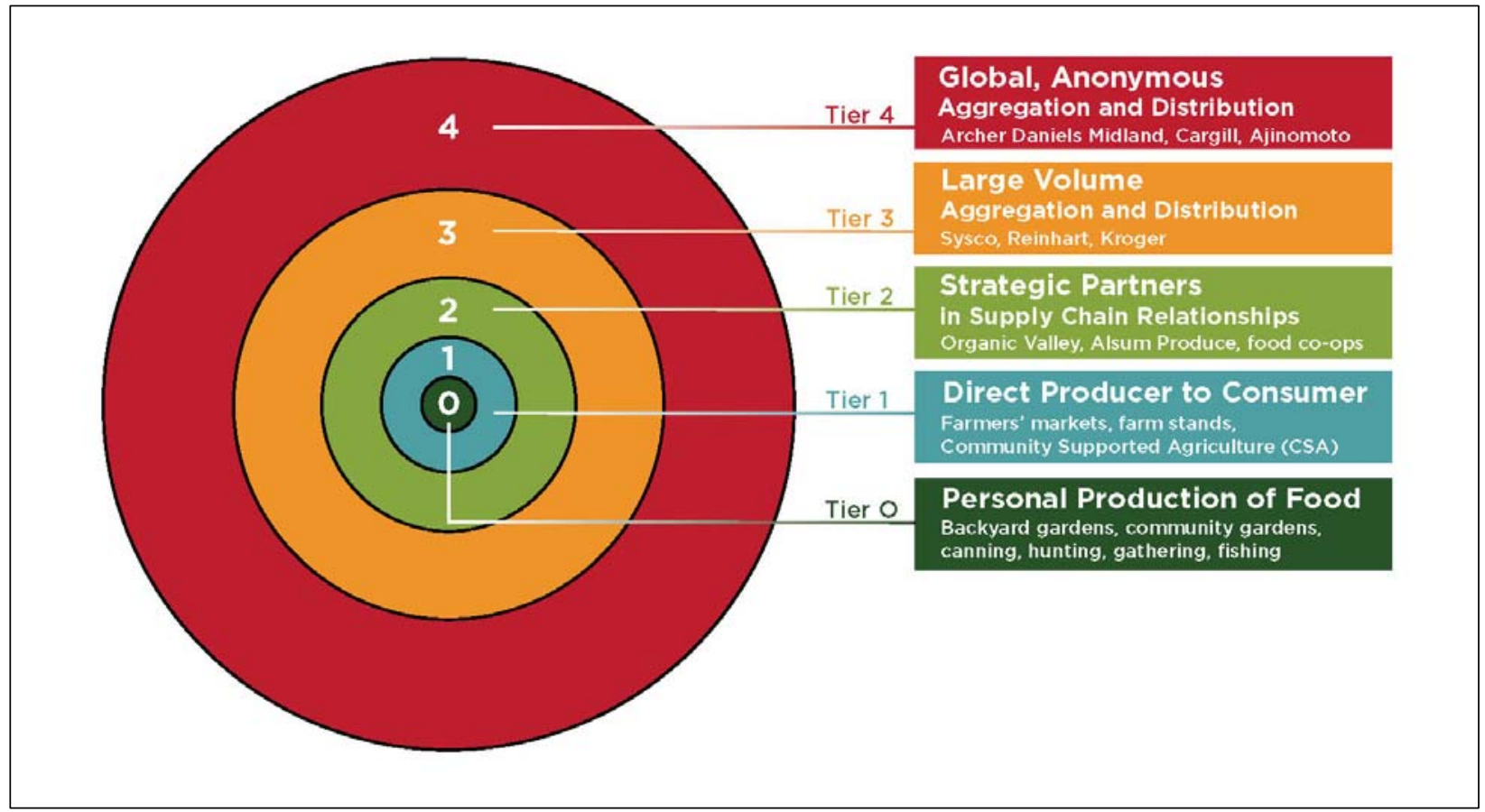

Image courtesy of University of Wisconsin-Madison Center for Integrated Agricultural Systems.

geographic distance) increase. As indicated in figure 2 , the most notable shift is the loss of transparency we observe as a consumer moves from the inner spheres of the diagram, which represent per-

sonal food production and direct-marketing, to the outermost sphere, which represents highly processed, global, anonymous food products such as energy drinks, chicken nuggets, and cheese puffs. Further examination reveals that this transparency also generally corresponds to the percentage of the retail food dollar captured by the farmer. For example, if you buy a pound of apples directly from the grower at a farm or farmers' market (high levels of transparency about product origin), the farmer gets to keep the total value of that sale (high percentage of the retail food dollar), but if you purchase a pound of apples at a grocery store (lower level of transparency about product origin), the retailer alone may retain 40 cents on the dollar (correspondingly, the grower retains a lower percentage of the sales price).
Arguably, the strength of direct-marketing strategies such as farmers' markets, CSAs, u-pick operations and other agritourism activities is two-fold: they are effective ways to help reconstruct the relationship between consumers and their food, and they can be economically beneficial for local producers. In this regard, direct marketing exemplifies the beneficial attributes of the local food system, evincing the claim that the local scale, insofar as it increases farmer-consumer proximity, is particularly well positioned to foster normative and descriptive values such as fairness and transparency in local food supply chains. Parenthetically, it is also worth mentioning that farmers' markets are not always profitable for producers. Even if a farmer can make US $\$ 5.50$ per quart for strawberries, she would have to sell more than 80 quarts of strawberries a week to make a living wage in Madison, Wisconsin, which is unlikely given the foot traffic and consumer-purchasing power at many farmers' markets. However, even when it is profitable for individual growers, direct marketing is an impractical means of moving high volumes of local prod- 
uct into venues such as retail grocery stores and cafeterias because farm-direct sales typically move small quantities of product, while retail and institutional buyers would prefer to buy larger volumes from fewer suppliers.

Further, research indicates that wholesale markets are not to be overlooked; according to a 2008 report by the Hartman Group, $62 \%$ of consumers say they primarily purchase local food at grocery retailers, making grocery retailers an important target market for local food producers. As the supply chain lengthens, producers selling into local wholesale markets need to find new ways to connect to buyers, particularly if they want to capture a premium for local product in the competitive grocery retail marketplace. ${ }^{3}$ Day-Farnsworth et al. corroborate other value(s) chains research findings that in order for producers "to capture a premium, buyers and consumers need to know about the unique origins of local and regional food, and how it is grown...in many instances, storytelling and transparency about production practices supersede third party certification as means of product differentiation" (2009, p. ii) Examples of local product branding and differentiation range from having instore meet-the-farmer product tastings to posting farm names and farmer profiles at the point of sale to affiliating with reputable regional brands. Other examples from three of the University of Wisconsin-Madison CIAS case studies are described in the appendix and in the discussion below.

\section{Fair Pricing}

As described above, in direct marketing, producers are typically price-makers insofar as they are able to set their prices as high as their markets allow. By contrast, producers who sell into commodity markets are typically price-takers and must capitulate to terminal market pricing regardless of their cost of production. Stevenson, Clancy, King, Lev, Ostrom,

\footnotetext{
${ }^{3}$ For example, if a local producer's apples are not farmidentified or labeled as local but they cost $10 \%-30 \%$ more than the nonlocal apples on the shelf next to them, producers and retailers alike will find it difficult to move the local apples even when market research points to a rising demand for local product.
}

\& Smith (2011) point to midtier supply chains as a potential "sweet spot," where economies of scale meet socially and environmentally differentiated product, making it possible for meaningful price negotiations to take place between producers and buyers. Price negotiation is at the crux of strategic supply chain relationships because it implies an interdependency between producers and buyers and suggests that both parties recognize the value that the other brings to the partnership. For buyers, the benefit likely pertains to product quality and consistency in supply; for producers, the benefit is a fair price for their product and access to markets they may not be able to reach through direct sales. As a rule, fair pricing hinges on costof-production, wherein producers must have working knowledge of their input and labor costs and in turn receive "cost-of-production plus" prices that cover the cost of production and incorporate profit margins along the value chain.

Several key lessons emerge from this brief overview of aggregation, transparency and source identity, and fair pricing. First, product aggregation is possible at every point along the supply chain. Second, as supply chains lengthen, product volume usually increases while farm identity is lost. Bolstering marketing and merchandising efforts that tell a farm and product's story is an effective approach to resolving the loss of transparency and source identity and helps producers capture a premium for local products sold through grocery retailers and institutions. Finally, price negotiations based on cost-of-production-plus-profit pricing help ensure that premiums captured in highvolume transactions are fairly distributed across the supply chain. Altogether, these lessons imply flexibility in supply chain design, but they also raise questions about the costs and benefits of different supply chain configurations and branding strategies. Our research explored how organizations responded to distinct circumstances in organizing food value(s) chains. 


\section{Comparative Case Study Analysis}

\section{The Baldwin Local Food Distribution Project}

Since 2008, a growing number of case studies have investigated the inner workings of community food systems and regional food distribution networks (see Barham, 2008; Dreier \& Taheri, 2008; Maye, Holloway, Kneafsey, 2007; Starr, Card, Benepe, Auld, Lamm, Smith, \& Wilken, 2003; and Zajfen, 2008). The majority of these are exploratory case studies focused on farmers' markets, CSAs and other predominantly farm-direct distribution methods. While these studies have generated a wealth of information about the innovations and challenges on the ground, case studies of individual organizations are not designed to discover variation in the goals and organization of food distribution. Furthermore, little existing research peers into the "black box" logistical and organizational bottleneck through which food flows in intermediated food supply chains, i.e., supply chains that incorporate distribution and/or logistics partners other than the farmer and the buyer. Launched in January 2008, the University of Wisconsin Baldwin Idea grant program funded the Center for Integrated Agricultural Systems to establish the Local and Regional Food Distribution Project with the goal of understanding how various successful midscale local and regional food distributors function and the barriers they face, in order to develop appropriate programmatic, policy, and regulatory remedies.

\section{Methods and Research Questions}

Our research used the working hypothesis that organizations involved in midsized regional food distribution were pursuing different goals by different organizational strategies than those of the "industrial" food system. We based this working hypothesis on the fact that food value(s) chains, like "fair trade" supply chains, would necessarily incorporate goals and organizational models distinct from organizations devoted mostly to maximizing profit. The central research questions of the Baldwin study were three: what are the organizational and operational characteristics of successful midscale regional distribution operations? How are these characteristics expressed across the case studies? And what barriers and opportunities do these organizations encounter in their efforts to distribute local product?

Researchers initiated collaborations with the Wallace Center ${ }^{4}$ and the United States Department of Agriculture (USDA) who were independently pursuing research on food distribution. While the population of values-driven food distribution organizations is growing rapidly, no professional associations exist in this organizational landscape, so there was no formal clearinghouse to approach for a comprehensive list of organizations involved in midsized regional food distribution. Therefore, these collaborations expanded our sample size, which enabled us to increase the scope of the Baldwin project beyond Wisconsin to capture innovations in other parts of the country. Researchers used systematic, snowball, and purposive sampling strategies to establish a database of 68 food distribution entrepreneurs serving local or regional markets. This database included the work of the Wallace Center, webinar participants in the USDA Cooperative State Research Education and Extension Services Family Farm Forum (USDA CSREES, 2008), and attendees from the 2008 Community Food Security Coalition conference. Our initial interviews with nearly two dozen businesses gave us an understanding of the range of goals, business models, and organizational strategies. We used this preliminary analysis to select 11 organizations for more in-depth analysis (an initial report is Day-Farnsworth et al., 2009). Since we were interested in exploring the organizational and ideological diversity of the mediating organizations in the industry, we selected cases on three criteria: (1) representation of diverse locations, scales, and forms of business organization; (2) emphasis on enterprises supplying primarily wholesale markets (e.g., grocery retailers, broadline distributors, institutional food service operators, and restaurants); and (3) aggregation and distribu-

\footnotetext{
${ }^{4}$ The Washington, D.C.-based Wallace Center at Winrock International utilizes research, policy analysis, and education to support market-based reforms to the food system (Winrock International Wallace Center, 2009). See http://www.winrock.org/wallace/
} 
tion models that share the characteristics of value(s) chains as defined at the outset of this article. Based on ongoing analysis, we selected three organizations whose work made for particularly clear and illustrative lessons about how midtier food value(s) chains are developing; other writing projects will elaborate these developments and appropriately amplify the discussion here.

Thus, given the exploratory nature of our work, we asked, "what is this organization, activity, or practice a case of?" instead of, "where are the cases that fit a particular idea about food distribution?" Again, generalization was not our goal; identifying and comparing practices were our fundamental tasks. At each of our three rounds of interviews we reviewed and fine-tuned our interview guide, vetting and testing it prior to reengaging our selected organizations. Then we conducted in-depth phone interviews with CEOs or high-level managerial or marketing staff from each organization. Follow-up communications clarified and expanded on information that surfaced in the interviews. We followed the typical protocol of questioning our interviewees to the "saturation" point, i.e., the point where we were no longer learning new information. The case studies referenced here were selected for their unique approaches to incorporating normative and descriptive values outlined in the Principles of a Healthy Sustainable Food System pronouncement, such as fairness and transparency through particular mixtures vis-à-vis supply chain configuration, price-setting, and marketing.

\section{Discussion}

The following is a discussion of key themes issuing from the Baldwin case studies as they pertain to our core interests in aggregation, transparency and source identity, and pricing. Illustrative examples are drawn from three organizations (The Organic Valley Produce Program, Co-op Partners Warehouse, and Community Alliance with Family Farmers) to illuminate specific challenges and innovations to midtier food value(s) chains. The variation across these organizations demonstrates that there are multiple ways midvolume food value(s) chains can wed the transparency and higher producer returns typical of direct marketing with the volume, efficiency, and regulatory climate characteristics of larger-scale food operations. Each subsection concludes with examples of how planners and allied professionals can foster improvements in midvolume local and regional food distribution. An overview of each organization and description of these components of their operations are provided in the appendix.

\section{Aggregation}

Each of the organizations profiled in this article aggregates product from tens of small and midsize producers. Tracking relatively small volumes of product from multiple sources and ensuring quality and consistency across commingled product can be difficult without adequate systems. These case studies point to a need for improved post-harvest handling infrastructure that would allow for better quality control through centralized grading and packing facilities and more efficient transport. Two distinct but related issues emerged in this regard: first, expanded physical infrastructure is needed to facilitate these activities, and secondly, business savvy is needed to appropriately pace such expansion. Here we elaborate on these issues with examples from the case studies and discuss ways in which planning professionals could support these activities and improve coordination between business decisions affecting economic development (e.g., business siting, financing, and expansion) and transportation planning considerations.

One of the challenges with improving quality control and transportation involves securing funding for infrastructure development. Traditional grant and loan options can be difficult to secure for small and midsized growers and food distributors because of perceived risk by funders. However, financing strategies historically utilized by urban and regional planners for commercial development are starting to be employed to fund "food hubs," which are centralized (often multi-organizational) facilities designed for grading, packing, and processing product. These financing strategies may present promising alternatives. For example, recent efforts in St. Louis, Missouri, successfully leveraged US $\$ 4.5$ million in Tax Incremental Financing (TIF) funds as part of the total financing package for the 
St. Louis Food Hub (Randol, 2011). Similarly, some rural areas have effectively leveraged public funds to help build rural economies through foodbased business and infrastructural development. In August 2010, the city of Viroqua and the Vernon Economic Development Association in Vernon County, Wisconsin, received a US $\$ 2$ million grant from the U.S. Economic Development Administration to help convert an empty manufacturing plant into a local food hub (Wisconsin Department of Commerce, 2010).

Another important finding of the Baldwin research was that rather than expanding immediately into processing, storage, and distribution, both Organic Valley and Co-op Partners Warehouse took phased approaches to infrastructural expansion. Each produce operation was or is still reliant on a parent company to provide storage or manage logistics. Co-op Partners Warehouse also uses a third-party hauler for distribution outside the Twin Cities (Minneapolis and St. Paul, Minnesota), further reducing its in-house responsibilities. This combination of asset-based development (building out from existing strengths) and regional outsourcing significantly reduces infrastructure-related costs.

By contrast, the Growers Collaborative (previously a distributor operated by Community Alliance with Family Farms) invested in too much infrastructure early on and found itself facing mission drift as it attempted to simultaneously provide producer education and marketing and operate a distribution enterprise. It ultimately opted to reconfigure its supply chain and pull out of delivery so that it could focus on supporting its growers with training and marketing. These findings may be of value to economic development planners, who can work with transportation planners to develop economic incentives and partnerships that facilitate assetbased and phased development strategies that will be more effective in the current economic climate. Specifically, collaborative research and planning efforts between metropolitan planning organizations, regional freight coalitions, and academic bodies such as the Center for Freight Infrastructure Research and Education (CFIRE) may be an effective way to integrate existing expertise in freight movement optimization with nascent efforts to build midtier food distribution networks. ${ }^{5}$

In summary, we urge planners, policy-makers, and allied professionals to advocate for and identify innovative funding strategies to help finance the expansion of physical aggregation and distribution infrastructure such as food hubs. At the same time, we caution entrepreneurs and technical assistance providers to pace physical infrastructural expansion appropriately so as not to overextend financially or programmatically. As the Baldwin case studies illustrate, there are multiple ways to configure supply chains. Aggregation can occur in a multiorganizational food hub and logistics can be outsourced until an organization has the resources to administer these activities in-house. With the right supply chain partners, a distributor may choose to never fully vertically integrate. Finally, we see a role for economic development and transportation planners in particular to improve coordination in regional planning and development. Their knowledge of freight and transportation networks, along with knowledge of creative public financing strategies, makes them uniquely equipped to foster context-sensitive approaches to community and regional food systems development, thus augmenting efforts by the private sector.

\section{Transparency and Source Identity}

All of the Baldwin case studies emphasized the importance of telling the story behind the product. For small growers accustomed to farm-direct sales, cultivating retail and institutional accounts and developing marketing and merchandising materials can feel foreign. Yet without this market savvy, local producers will likely find it difficult to compete in higher volume markets without significantly dropping their prices. Planners might assist producers new to retail and food service markets by

\footnotetext{
5 The Center for Freight Infrastructure Research and Education initiated its first research on local food transport with the University of Wisconsin-Madison Center for Integrated Agricultural Systems in 2010. The final report Maximizing Freight Movements in Local Food Markets is available at: http://www.wistrans.org/cfire/documents/CFIRE 0423 Final Report.pdf
} 
partnering with or directing them to private and nonprofit local food marketing resources.

The Community Alliance with Family Farmers promotes product from different farmers under the Buy Fresh Buy Local banner and is developing educational materials about local products as well as marketing and merchandising strategies for every phase of the supply chain. The unified banner simplifies brand recognition for consumers, who are otherwise confronted with the names of many farms. Further, the brand elevates the visibility of a variety of products and producers from a given geographic area. Organic Valley's produce program capitalizes on the brand recognition developed by its well established dairy program. And Co-op Partners balances a variety of approaches ranging from co-branding its deli products with the National Cooperative Grocers Association to allowing farms to directly manage their sales and marketing to on-farm experiential education through the Gardens of Eagan Farm. Other Baldwin case study subjects use in-store product samplings and meet-the-farmer activities to help forge personal connections to reinforce farm and/or brand name.

As many planning subspecialties are similarly concerned with promoting the relationship between person and place, the integration of community and regional food production and consumption is a natural fit for new metropolitan plans, several of which explicitly seek to promote local sustainable food. The Chicago Metropolitan Agency for Planning (CMAP) recommends a three-pronged strategy in its "GO TO 2040" plan that calls for:

1. Facilitating sustainable, local food production and processing;

2. Increasing access to safe, fresh, nutritious, and affordable foods; and

3. Raising awareness [to help public officials, planners, and residents understand and support investments in sustainable local food] by providing data, research, training, and information.
Increasing the visibility of local food production and elevating access to healthy food to a metrolevel priority will help raise the profile of the local food system in planning and policy efforts.

However, to advance the objectives detailed in the CMAP plan, resources and attention will also need to be devoted to the behind-the-scenes work of building relationships between producers, aggregators, and mid- and high-volume buyers. Planners can, and in some instances already are, serving the function of relationship brokers. The Institutional Food Market Coalition (IFM), a project of the Dane County (Wisconsin) Planning and Development Department, was launched in 2006 as a public-private partnership designed to develop institutional markets for local food. The IFM has worked closely with the Wisconsin Department of Agriculture, Trade and Consumer Protection and has successfully leveraged state and county funds to conduct outreach, education, and technical assistance, and to facilitate sales between Wisconsin producers, institutions, distributors, produce auctions, and local food businesses. In 2010 the IFM facilitated over $\$ 2.5$ million in sales of Wisconsin local food and helped create or retain 29 jobs (IFM, 2011).

\section{Fair Pricing}

While no two organizations examined in the Baldwin study employed the exact same pricing and payment strategies, certain themes did emerge across the case studies. Notably, prices were typically negotiated and were generally higher than terminal market prices. Further, to anticipate demand and increase negotiating power, several cases noted the importance of producer-toproducer and producer-buyer meetings to coordinate production planning and align supply and demand in advance of the growing season. This can be achieved informally by convening local producers who sell to the same accounts or more formally within a coordinated pool of producers. Higher levels of producer coordination seem to allow for more sophisticated pricing mechanisms, as is the case with the Organic Valley Produce Program described below. 
The Organic Valley case study offers a compelling model of both fair pricing and collaborative producer-distributor partnerships. By offering its producers a base price along with an end-of-season "pooling bonus," Organic Valley ensures that growers receive regular payments for their product. It also utilizes the pooling bonus mechanism as a way to build in flexibility to accommodate freight costs and some price fluctuation over the course of the season. What profits remain at the end of the season are then equitably redistributed. Organic Valley also illustrates the value of educating growers about the cost of production pricing and postharvest handling. Taking a holistic approach to supply chain improvements, Organic Valley has made considerable investments in grower workshops and other resources to improve its growers' capacity, its product quality, and the fairness of its pricing.

Co-op Partners Warehouse's two-pronged distribution model raises another pricing issue for midtier value(s) chains: producers unfamiliar with highvolume markets are not always knowledgeable about pricing variability and mark-up practices. As a result, producers who sell product through Co-op Partners' drop-ship program and under the Co-op Partners banner may sell the product at the same cost to each venue, making the retail price for a product sold through (and thus marked-up by Coop Partners Warehouse) more expensive than the exact same item sold farm-direct. This can create tension between producers, Co-op Partners Warehouse, and their shared retail customers, but as the co-op's director of business development noted, "Experienced growers usually avoid this issue and stabilize sales by charging different prices for direct sales and those made through a distribution." Training for producers on wholesale pricing can also obviate these types of conflicts, and planners can foster education and technical training to advance mutually beneficial economic outcomes. Thus planners involved in rural development or working in coordination with cooperative extension may wish to coordinate cost-of-production and cost-of-distribution trainings in conjunction with agricultural economic development projects to help ensure that public investments in local proc- essing and distribution are not stymied by assumptions about price points that fail to reflect the cost of production.

Planners are not typically engaged in helping establish product prices, but they do foster local and regional economies and so they need to understand how pricing mechanisms might influence their practices. Price negotiation is fundamental to fair pricing for producers and an important component of strategic supply chain relationships because it implies interdependency in supply chains. Buyers benefit from strong, mutually beneficial relationships with their producers because they contribute to improved product quality and consistency in supply. Producers benefit from increased market access, more loyal customers, and in some instances technical assistance. Planners can help establish collaborations that satisfy economic needs.

The creative organizational practices highlighted here show innovations in midtier food value(s) chains and how planners might foster the values and objectives driving the development of these chains as well as the innovative role these developments can play in creating resilient regional food systems. Further, the empirical examples serve to illustrate some of the ways social values can be built into the DNA of food distribution operations rather than functioning solely as ancillary or parallel objectives. Local and regional food systems are being reenergized by the diversity of expertise they are attracting, and they are fueling unprecedented collaboration between fields as distinct as urban and regional planning and nursing. Allied professionals from a wide range of professional backgrounds can assist entrepreneurs, growers, and other public and private partners to improve regional wholesale efficiencies, market access, farmer parity, and food security. The following section focuses on the following strategic interventions: infrastructure assessment and planning, regional economic development, and improved alignment of regulatory infrastructure. 


\section{Implications for Professional Planning}

This section steps back from the details of how organizations are reconstructing distribution systems into high volume, midtier food value(s) chains to elaborate recommendations for planners and other professionals interested in assisting organizations in meeting consumer demand and jurisdictions in meeting their goals for economic development (as initiated by community food assessments (Pothukuchi, 2004)). Here our goal is identifying the next steps policy professionals should take to facilitate the swift integration of food value(s) distribution systems into the everyday activities of economic development, land use, transportation, and other planning and policy fields. Doing so will multiply place-based food distribution networks able to balance the social and ecological benefits of the alternative food system with the economic and scalar efficiencies of the industrial food system. As this special issue and the authors share a professional and academic orientation in urban and regional planning, the following interventions emphasize the field of planning but are broadly applicable to allied professionals engaged in food systems development.

\section{Conduct Infrastructure Inventories}

The aggregation efforts of the food distribution businesses exemplified by the organizations discussed in this article illustrate two major lessons for professionals and other businesses: efficient aggregation is increasingly being orchestrated at multipurpose (and sometimes multi-organizational) food hubs, and infrastructural investments are costly, which makes asset-based and phased development strategies particularly effective. To strategically advance asset-based food systems development, we must first have a working knowledge of regional food systems' present assets (such as existing processors, distributors, and transportation networks) and how those assets are interconnected. Regional food system inventories or asset-mapping (tailored predominantly to wholesale infrastructure and distribution) would significantly help with the practical work of rebuilding sustainable regional food systems and the physical infrastructure that supports them.
Planners are familiar with such efforts and use them in land use planning of various kinds. Such inventories are used in other professional fields as well. For example, the Land Trust Alliance (LTA), the national authority on land trust standards and practices, requires baseline documentation reports (BDRs) of all conservation properties prior to conservation transactions. BDRs document a property's conservation values and guide its management plan as stipulated by the LTA's code of ethical and technical guidelines (Land Trust Alliance, 2004). Likewise, energy audits, standard practice on the institutional scale as a precursor to energy efficiency facility upgrades, can identify the types of energy improvements that will yield the greatest return on investment. While distinct, these examples illustrate the broad range of application and referential weight given to inventories in fields utilizing baseline information to help preserve or improve upon the status quo.

Hundreds of community food assessments (CFAs) - participatory processes that systematically examine a broad range of community food issues and assets to inform change to make communities more food secure — have already been implemented at a variety of scales by planners and community food security advocates. While CFAs typically focus on issues of food quality and access, some have incorporated components that examine larger scale, infrastructural issues. Building on this precedent but with an eye toward regional and economic development, asset maps could detail a number of features: existing profit and nonprofit food distributors; food processors; the processing capacity of kitchen facilities at regional institutions such as churches and schools; freight transportation networks; temperature-controlled storage facilities; agricultural entrepreneurs, investors and loan guarantors; current and projected regional production capacity; cooperative extension resources; grocery and retail outlets; and other high-volume local markets including prisons, school systems, universities, nursing homes, and corporate campuses. A baseline regional food system inventory would achieve the following goals: 
- Help identify gaps and patterns within the current landscape;

- Point to opportunities for partnerships;

- Lend legitimacy to project proposals and funding requests that seek to strengthen and scale up sustainable regional food systems;

- Serve as a yard stick against which to chart and assess future progress;

- Identify existing infrastructure, including distribution centers and storage facilities that could serve as food hubs; and

- Inform siting decisions about new processing and distribution facilities based on production areas and transport infrastructure.

The private planning firm Vandewalle \& Associates of Madison, Wisconsin, funded by the Kellogg Foundation, has already begun working with colleagues at the Michael Fields Agricultural Institute, Blue Planet Partners, and University of WisconsinMadison to conduct a preliminary asset analysis of the Upper Midwest in conjunction with the Good to Grow Initiative (Vandewalle \& Associates, 2007).

\section{Foster Regional Development of Allied Industries}

One systemic strategy for increasing transparency and maintaining information about source identity throughout a midtier food value(s) chain is to foster regional development of allied industries. The produce businesses discussed in this article primarily convey information about production practices and product origin through enhanced marketing and merchandising techniques. However, the development of "food clusters" could offer several advantages to local producers by helping to facilitate value(s) chain formation and place-based marketing. These benefits could range from strictly infrastructural and logistics improvements associated with strategically siting processing facilities near significant production areas to creating enhanced marketing opportunities resulting from the development of regional culinary identities. While the attraction and development of allied industries would advance rural development objectives through job creation, the cultivation of a regional culinary identity could also promote foodrelated tourism opportunities.

Contemporary business literature substantiates these ideas by emphasizing the distinct advantages of increased innovation, workforce development, and competitive edge associated with industrial clusters (Porter, 1998; Saxenian, 1994). Most famously illustrated by the wine consortium in northern California, "clusters are geographic concentrations of interconnected companies and institutions in a particular field" (Porter, 1998, p. 8). Clusters encompass a variety of allied industries and related expertise and investment, such as suppliers of specialized inputs (e.g., machinery, services, and providers of specialized infrastructure), trade associations, universities, and government institutions, as well as financial institutions and investors (Porter, 1998).

By fostering connectivity through trade synergy and geographic proximity, clusters represent a means to achieve not only a competitive national and international advantage, but also regional economic development. Economic development specialists in particular can play an important role in developing those organizations, and when needed, reconciling these various private and public purposes in institutionalizing value chain characteristics into the relationships that constitute the clusters. Supporting independent businesses could simultaneously help fill gaps in regional food systems, build entrepreneurial capacity, and foster regional economic development.

One theme emerging from the Baldwin case studies is a need for greater investment in and development of midsize processing infrastructure. Vegetable processors, once prolific across portions of the Midwest, have declined over the past three decades, paralleling the consolidation of the industrial food system (Hinrichs \& Lyson, 2007). Likewise, many food service providers at institutions (hospitals, schools, universities, and prisons) interested in sourcing locally have lost their capacity to prepare fresh product. As a result, without sufficient, affordable processing infrastructure, growers and local food distributors are losing a significant 
portion of their potential market, and palatable food is going to waste. All three businesses highlighted here cited the need for processing to add value, to incorporate blemished products into the value stream, and to increase access to institutional and retail markets that prefer to purchase processed products over whole products.

Lastly, the success of the wine consortium in Northern California is not only a function of the geographic proximity and high levels of exchange between suppliers, manufacturers, trade associations and supportive research and funding entities; it is also a result of the fact that wine consumers both inside and outside the region began to conceive of Northern California as a premier wine grape-growing region. Similar efforts are underway in the Driftless Region (see figure 3), a geologically defined 24,000-square mile area situated along the upper Mississippi River Valley of Minnesota, Wisconsin, Iowa, and northwestern Illinois. In 2009, the region became formally recognized as the Upper Mississippi River American Viticultural Area. Also home to the largest number of raw milk cheeses and organic and CSA farms in Wisconsin, the Driftless Region is making a name for itself in the Upper Midwest and beyond. Perhaps it's not an accident that both Organic Valley and Co-op Partners Warehouse are located in or adjacent to the Driftless Region.

Strategic development of cognate industries, such as processing, would support regional wholesale food distribution, thus advancing the following goals:

- To deliver more local product to larger volume regional markets;

- To enhance access to fresh and fresh-frozen local product for consumers in institutions such as schools and hospitals;

- To reduce food miles traveled by food consumed in the region;

- To retain more food dollars in regional economy;
- To foster community economic development, which as distinct from "economic growth" is characteristically long-term, purposeful, and permanent and increases communities' capacity to act and innovate (Shaffer, Deller, \& Marcouiller, 2006); and

- To enhance opportunities for placed-based marketing through cultivation of regional culinary identities.

Professionals active in local and regional food system development should recognize that significant philanthropic and federal grant opportunities exist to establish new organizations and collaborations for existing organizations. Regional planners, public-sector staff, and consultants can help ensure successful applications by assisting organizations and alliances in integrating various elements of the food system appropriately when responding to various request-for-proposal guidelines and by supporting related research assessing these various initiatives.

\section{Realigning Regulatory Policy with Small- to Midscale Production and Distribution}

The food regulatory system is largely designed to ensure food and workplace safety by standardizing and monitoring the industrial food system. As a result, current regulations present numerous challenges to small- and midscale growers and distributors whose production scale and distribution range are often incongruent with the particular regulatory costs and procedures associated with their trades. Additionally, as the price for a product frequently subsidizes or internalizes costs associated with regulation, incongruent regulations pose a challenge to small- and midscale producers in setting prices. While clusters or similar initiatives can facilitate fair pricing, such prices will also likely require complementary policy work to address scalar incompatibilities between these midtier efforts and the current regulatory structure.

Following the recent series of food recalls across the country, trade associations and consumer advocates alike have become increasingly vocal about the need for food safety reform (Harris \& 
Figure 3. The Driftless Area of the Upper Mississippi River Valley

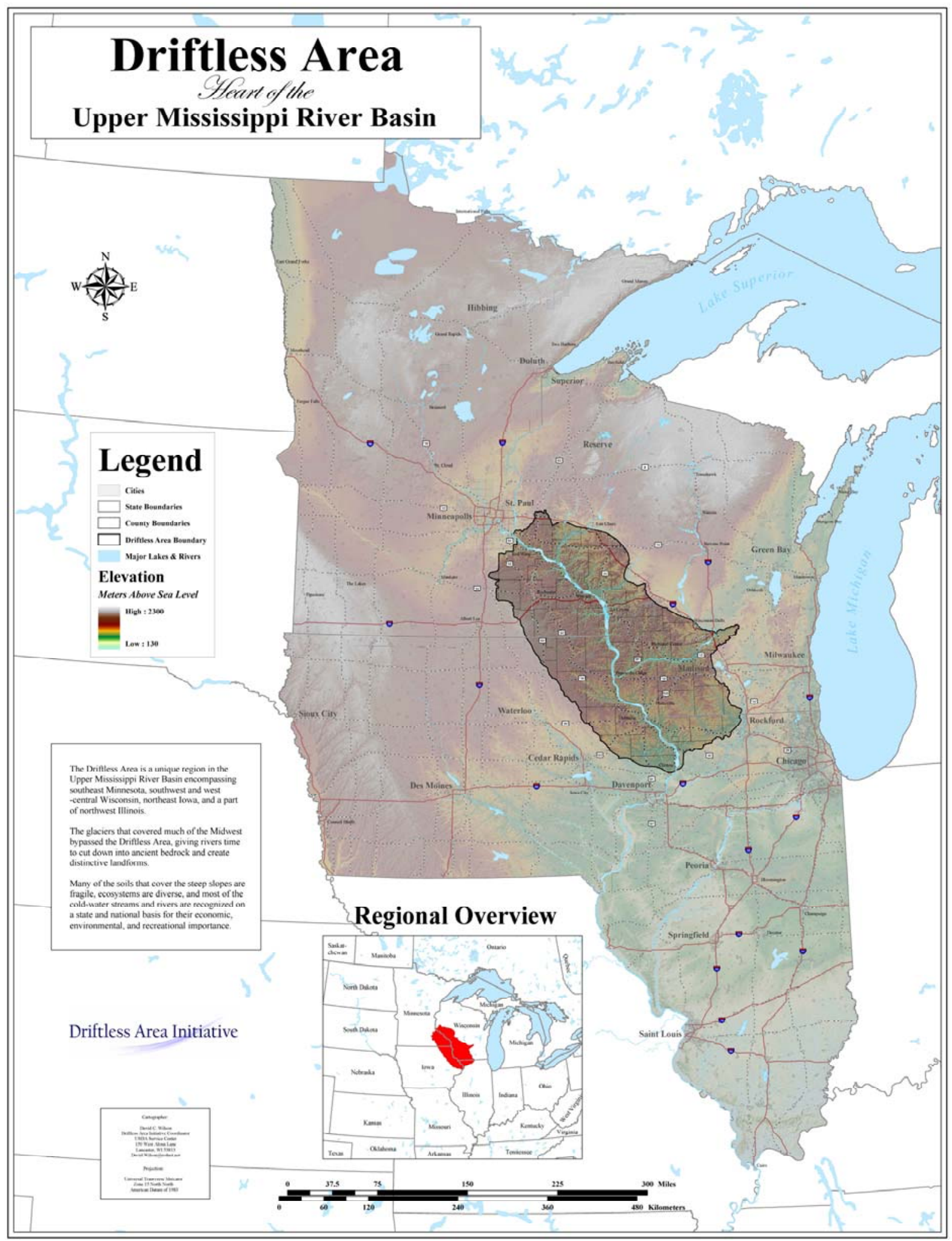

Image courtesy of the Driftless Area Initiative. 
Belluck, 2009). However, research indicates that regulations poorly tailored to small- and midscale enterprises are both inconsistently enforced and often inadequately implemented (Yapp \& Fairman, 2006). By partnering with state departments of agriculture, trade, and public health, cooperative extension, consumer watchdog groups, trade associations, nonprofits and policy-makers at the county, state, and federal levels, professionals supporting the development of local and regional food systems could help facilitate the formation of a regulatory framework that would achieve the following:

- Increase food safety and consumer trust in the regulatory system;

- Enhance interstate regional trade opportunities by fostering reciprocity agreements through which production and processing standards are streamlined or equivalencies are formally recognized as is the trend within some international food trade networks (Woolthuis, Laknhuizen, \& Gilsing, 2005);

- Leverage county, state, and federal economic development grants to help growers and processors cover the infrastructure costs associated with GAP certification, the development of Hazard Analysis \& Critical Control Points (HACCP) plans, and mandated facility upgrades;

- Improve accessibility, clarity, and consistency of regulatory policy for emergent farmers and local food entrepreneurs and distributors through resources such as toolkits tailored to the distinct phases of a variety of regional wholesale supply chains;

- Improve small- and midscale food enterprises' regulatory compliance; and

- Invest in site planning, design, and other assistance to facilitate food distribution.

In short, government has an important role to play in developing a level regulatory and infrastructural playing field for midtier distribution. Such efforts will facilitate the development and growth of new enterprises with their associated economic and social benefits. Finally, the foregoing recommendations associated with inventories and assessments, economic development and organizational design, and regulatory frameworks, can all be implemented by multidisciplinary planning offices, both public and private. Clearly planners have much to offer in this important element of food system practice. We feel that advocates and allied professionals are also central to advancing these steps.

\section{Conclusions}

Despite the relative absence of wholesale distribution in much of the planning profession's academic and grey literature, emerging models promise to remake the relationship between producers and their regional markets. In this article, key lessons from the value(s) chain literature were illustrated with examples from comparative case studies conducted by the University of WisconsinMadison Center for Integrated Agricultural System to acquaint professional planners and allied professionals with strategies for imbuing mid- to highvolume local food distribution with normative values such as transparency and fairness. The research presented here is not a comprehensive analysis of regional wholesale food distribution. Rather, we have focused on organizational, logistical, and marketing characteristics of local and regional food value(s) chains.

Strategic planning and collaborative trans-sectoral solutions will be necessary to ensure that as regional food systems expand, they retain the goals and values outlined in the Principles of a Healthy Sustainable Food System. The opportunities for public health professionals, rural development specialists, urban and regional planners, policy-makers and others to advance these objectives are numerous. Here we highlighted interventions particularly well suited to planning professionals. We first built on University of Wisconsin-Madison CIAS case studies to identify how planners could augment aggregation, marketing, and fair price negotiations to foster the development of midtier food value(s) chains. We then described larger system interven- 
tions that regional planners could employ to better accommodate midtier food distribution needs in the regional planning and food regulatory environment: documentation of existing wholesale food system infrastructure; incorporation of agricultural industry clusters into regional economic and community development planning and the cultivation of regional culinary identities; and lastly, the development of partnerships with policymakers and food safety regulators through zoning and regulatory policy to foster regulation that both protects public safety and welfare while also building the capacity and market access of local food entrepreneurs.

\section{Acknowledgments}

The authors would like to thank Michelle Miller, Brent McCown, Anne Pfeiffer, and the Ira and Ineva Reilly Baldwin Wisconsin Idea Endowment for making the Local and Regional Food Distribution project possible. We extend our gratitude to the University of Wisconsin Center for Integrated Agricultural Systems (CIAS) for allowing us to use the case studies examined in this paper and for granting permission to include figures 2 and 3 . Thanks also the Center for Freight and Infrastructure Research and Education (CFIRE) for student support, and finally to editors and reviewers at JAFSCD, as well as Jerry Kaufman, Cris Carusi, Anne Pfeiffer, Steve Stevenson, Ken Meter, Jacki Hartley and Elise M. Gold, for their feedback on earlier versions of this article. This research was supported by the United States Department of Agriculture National Institute of Food and Agriculture (USDA award 2011-68004-30044).

\section{References}

American Dietetic Association, American Nurses Association, American Planning Association, and American Public Health Association. (2010, June). Principles of a bealthy, sustainable food system. Retrieved from http://www.planning.org/national centers/health/pdf/HealthySustainableFood SystemsPrinciples.pdf

American Planning Association. (2007). Policy guide on community and regional food planning. Retrieved from http://www.planning.org/policy/guides/adopted/ food.htm
Barham, J. (2008). Assessing alternative food distribution models. PowerPoint presentation. USDA Marketing Services Division.

Day-Farnsworth, L., McCown, B., Miller, M., \& Pfeiffer, A. (2009). Scaling up: Meeting the demand for local. University of Wisconsin Cooperative Extension, Center for Integrated Agricultural Systems.

Day-Farnsworth, L., Bruner Zimmerman, A., \& Daniel, J. (Forthcoming). Proceedings from Making Good Food Work Conference.

Dreier, S., \& Taheri, M. (2008). Innovative models: Small grower and retailer collaborations (Good Natured Family Farms and Balls Food Stores). Wallace Center at Winrock International.

Grubinger, V. (2010). Ten reasons to buy local food. University of Vermont Extension. Retrieved from http://www.uvm.edu/vtvegandberry/factsheets/ buylocal.html

Harris, G., \& Belluck, P. (2009, January 29). New look at food safety after peanut tainting. New York Times.

Hartman Group. (2008). Consumer pulse: Consumer understanding of buying local. The Hartman Group.

Hinrichs, C., \& Lyson, T. (2007) Remaking the North American food system: Strategies for sustainability. Lincoln: University of Nebraska Press.

Institutional Food Market Coalition (IFM). (2011, March). Dane County Institutional Food Market Coalition 2010 program report. Dane County Planning \& Development Department. Retrieved from http://lgc.uwex.edu/Downtowns/DOC/Apr11/ IFM $\% 202010 \% 20 \operatorname{Prog} \% 20$ Rep $\% 20$ FINAL $\% 20$ FOUND-READINGS.pdf

Land Trust Alliance. (2004). Land Trust Standards and Practices. "Standard 11: Conservation Easement Stewardship." Retrieved from http://www.landtrustalliance.org/training/sp/ lt-standards-practices07.pdf

Lev, L., \& Stevenson, G. W. (2011). Acting collectively to develop midscale food value chains. Journal of Agriculture, Food Systems, and Community Development, 1(4), 119-128.

Maye, D., Holloway, L., \& Kneafsey, M. (Eds.). (2007). Alternative food geographies: representation and practice. Oxford: Emerald Group Pub Ltd.

Morales, A. (Forthcoming). Growing food AND justice: Dismantling racism through sustainable food systems. In A. Alkon \& J. Agyeman (Eds.). Cultivating food justice: Race, class and sustainability. Cambridge, Massachusetts: MIT University Press. 
Porter, M. E. (1998). Clusters and the new economics of competition. Harvard Business Review, 76(6), 77-90.

Pothukuchi, K. (2004). Community food assessment: A first step in planning for community food security. Journal of Planning Education and Research, 23(4), 356-377.

Pothukuchi, K., \& Kaufman, J. (2000). The food system: A stranger to the planning field. Journal of the American Planning Association, 66(2), 113-124.

Randol, J. (2011, July 21). Farm Fresh Food Hub Services, St. Louis, Missouri. Clearing the roadblocks: Market-based strategies for getting good food to all communities [National Good Food Network webinar]. The Wallace Center at Winrock International.

Saxenian, A. (1994). Regional advantage: Culture and competition in Silicon Valley and Route 128. Cambridge, Massachusetts: Harvard University Press.

Shaffer, R., Deller, S., \& Marcouiller, D. (2006). Rethinking community economic development. Economic Development Quarterly, 20(1), 59-74.

Starr, A., Card, A., Benepe, C., Auld, G., Lamm, D., Smith, K., \& Wilken, K. (2003). Sustaining local agriculture: Barriers and opportunities to direct marketing between farms and restaurants in Colorado. Agriculture and Human V alues, 20(3), 301-321.

Stevenson, G. W., Clancy, K., King, R., Lev, L., Ostrom, M., \& Smith, S. (2011). Midscale food value chains: An introduction. Journal of Agriculture, Food Systems, and Community Development, 1(4), 27-34.

Stevenson, S. (2009). V alues-based food supply chains: Executive summary. University of Wisconsin Center for Integrated Agricultural Systems. Retrieved from http://www.cias.wisc.edu/wp-content/uploads/ 2009/07/vcexecsum.pdf

Stevenson, S., \& Pirog, R. (n.d.). V alue-based food supply chains: Strategies for agri-food enterprises-of-the-middle. Ag of the Middle white paper. Retrieved from http://www.agofthemiddle.org/papers/valuechain. pdf

Stevenson, S., \& Pirog, R. (n.d.) Why worry about the agriculture of the middle? Ag of the Middle white paper. Retrieved from http://www.agofthemiddle. org/papers/whitepaper2.pdf
U.S. Department of Agriculture (USDA). (2009). Emerging market opportunities for small-scale producers: Proceedings of a special session at the 2008 USD A Partners Meeting. USDA Agricultural Marketing Service, Marketing Services Program. Retrieved from http://www.ams.usda.gov/AMSv1.0/ getfile?dDocName=STELPRDC5076556 \&acct $=$ wdmgeninfo

U.S. Department of Agriculture (USDA). (2009, April). Agriculture Deputy Secretary Merrigan highlights the 'Know Your Farmer, Know Your Food' initiative in Chicago. (News Release No. 0122.10). Washington D.C.: USDA. Retrieved from http://www.usda.gov/ wps/portal/usdahome? contentidonly $=$ true \& contentid $=2010 / 03 / 0122 . x m l$

U.S. Department of Agriculture (USDA), Cooperative State Research, Education, and Extension Services (CSREES). (2008, November). Local Food Systems. Family Farm Forum [webinar]. Retrieved from http://connect.extension.iastate.edu/p59924434/

Vandewalle \& Associates. (2007). Good to grow Regional food strategy. Retrieved from http://www.vandewalle.com

Winrock International Wallace Center. (2009, August 23). Success for family farms project. National Good Food Network Cluster Call [webinar]. Retrieved from http://www.vimeo.com/5957772

Wisconsin Department of Commerce. (2010, September 30). Governor Doyle announces ED A funding for Food Enterprise Center in city of Viroqua [press release]. Retrieved from http://www.commerce.state.wi.us/ NEWS/releases/2010/141.html

Woolthuis, R. K, Laknhuizen, M., \& Gilsing, V. (2005). A system failure framework for innovation policy design. Technovation, 25, 609-619.

Yapp, C., \& Fairman, R. (2006). Factors affecting food safety compliance within small and medium-sized enterprises: Implications for regulatory and enforcement strategies. Food Control, 17, 42-51.

Zajfen, V. (2008). Fresh fruit and vegetable distribution models for the greater Los Angeles area. Center for Food and Justice. Retrieved from http://blogsangeles. typepad.com/blogs_angeles/2008/06/report-onexplo.html 


\section{Appendix. Overview of Case Study Organizations}

\begin{tabular}{|c|c|c|c|}
\hline Enterprise & $\begin{array}{l}\text { Growers Collaborative (CAFF) } \\
\text { Davis, California } \\
\text { Nonprofit }\end{array}$ & $\begin{array}{l}\text { Co-op Partners Warehouse } \\
\text { St. Paul, Minnesota } \\
\text { Subsidiary of a natural foods co-op }\end{array}$ & $\begin{array}{l}\text { Organic Valley Produce Program } \\
\text { La Farge, Wisconsin } \\
\text { Producers co-op }\end{array}$ \\
\hline Overview & $\begin{array}{l}\text { Initially a program of the sustainable agriculture } \\
\text { nonprofit Community Alliance with Family } \\
\text { Farms (CAFF), Growers Collaborative was } \\
\text { launched in } 2003 \text { to connect new, small and } \\
\text { minority farms with regional institutions seeking } \\
\text { local product. Towards this end, the } \\
\text { organization made costly grant-funded } \\
\text { investments in delivery vehicles and storage } \\
\text { warehouses. Realizing that broadline } \\
\text { distributors dominated the regional institutional } \\
\text { food service market and that many institutions } \\
\text { lacked the capacity to process fresh product, } \\
\text { Growers Collaborative determined that it was } \\
\text { unlikely to capture a profitable percentage of } \\
\text { the market and opted to reevaluate its } \\
\text { business plan and organization. By August } \\
2010, \text { CAFF had shifted its focuses to (1) } \\
\text { providing technical assistance for producers, } \\
\text { and (2) providing education, marketing, and } \\
\text { branding under the Buy Fresh Buy Local banner } \\
\text { for produce buyers and household consumers. } \\
\text { As part of this transformation, it transferred its } \\
\text { produce handling and logistics activities to two } \\
\text { locally based private wholesale companies. }\end{array}$ & $\begin{array}{l}\text { Co-op Partners Warehouse is a certified organic } \\
\text { distributor that sells produce and a variety of } \\
\text { perishable and shelf-stable products. } \\
\text { Established in } 1999 \text { as a subsidiary of The } \\
\text { Wedge Natural Foods Co-op, Co-op Partners } \\
\text { Warehouse was formed in response to the } \\
\text { demand for greater representation of small and } \\
\text { local producers in the regional wholesale } \\
\text { produce markets. It helped fill the void left by } \\
\text { the decline of other regional cooperative } \\
\text { distributors, and now serves retail co-ops and } \\
\text { natural food stores throughout the Upper } \\
\text { Midwest, as well as some restaurant and } \\
\text { institutional accounts. Co-op Partners } \\
\text { Warehouse owns and operates a } 45,000 \\
\text { square foot (4,180 square meter) warehouse in } \\
\text { St. Paul. It has its own small fleet for local } \\
\text { deliveries, but distribution within the larger five- } \\
\text { state region (Illinois, lowa, Minnesota, North } \\
\text { Dakota, and Wisconsin) is achieved through a } \\
\text { partnership with Edina Couriers, an } \\
\text { independent hauling service. Co-op Partners } \\
\text { Warehouse assesses producers a small delivery } \\
\text { fee for its hauling services, but customers order } \\
\text { from and are billed by the producer. In recent } \\
\text { years, it has expanded to include a line of deli } \\
\text { products and purchased the Gardens of Eagan, } \\
\text { an organic farm and long-time vegetable } \\
\text { supplier to The Wedge Co-op. }\end{array}$ & $\begin{array}{l}\text { Organic Valley is a producer-owned cooperative } \\
\text { that sells organic dairy and soy products, meat, } \\
\text { eggs, and produce. Founded in } 1988 \text { as a } \\
\text { produce growers' cooperative, Organic Valley's } \\
\text { dairy program quickly became its primary and } \\
\text { most profitable focus. However, growing } \\
\text { demand for local produce has recently } \\
\text { bolstered Organic Valley's Produce Program. } \\
\text { The co-op sources most of its produce from } \\
\text { Amish growers in southwestern Wisconsin and } \\
\text { supplies supermarkets and distribution centers } \\
\text { in the Midwest, East and South. Organic } \\
\text { Valley's Produce Program encompasses } \\
\text { production, warehousing and sales. A produce } \\
\text { pool coordinator works with growers to } \\
\text { coordinate preseason planning. The } \\
\text { coordinator also visits each farm to review } \\
\text { quality standards and packing requirements } \\
\text { and to address production questions. Organic } \\
\text { Valley provides workshops for its growers on a } \\
\text { range of topics, including on-farm sanitation, } \\
\text { post-harvest handling, and pest management. } \\
\text { It also supplies its growers with product liability } \\
\text { insurance and is providing additional guidance } \\
\text { as they move toward receiving the USDA's } \\
\text { Good Agricultural Practices (GAP) certification. } \\
\text { Organic Valley helps growers meet wholesale } \\
\text { produce industry requirements that would be } \\
\text { difficult and expensive to meet individually. }\end{array}$ \\
\hline
\end{tabular}


In the current model, CAFF creates and expands market opportunities for local farmers by providing resources to familiarize growers with standards associated with institutional markets and technical assistance for institutional food service to bring local produce onto the menu. It has also conducted a local food market analysis and feasibility study for an Aggregation \& Marketing Center on California's North coast. Though it no longer serves an immediate aggregation and hauling function,

Aggregation CAFF infuses values into existing aggregation and distribution activities by building market access and capacity, and by enhancing the visibility of sustainable and family farmers.
Transparency

and Source

Identity
Co-op Partners Warehouse offers two

distribution services to its local food suppliers. Its drop-ship service enables buyers to place orders directly with local suppliers. In this program, Co-op Partners Warehouse provides a hauling function; the product transported is never part of Co-op Partners' inventory, and producers and buyers independently negotiate billing and invoicing. The drop-ship program reduces the need for local suppliers to each deliver separately to the same retail accounts. Co-op Partners serves a minimal aggregation role in this capacity. Co-op Partners Warehouse also operates a more traditional distribution operation in which it purchases product from suppliers, aggregates it at a central warehouse, and manages its own retail customer accounts. By providing both aggregation and hauling functions, Co-op Partners Warehouse meets the unique needs of its various supply chain partners while helping to increase the overall availability of local products in the marketplace.

CAFF's marketing and branding campaigns and educational programs work to increase consumer demand for and access to fresh, local produce by connecting household consumers and retail and institutional buyers with information about local producers and seasonably available products. CAFF has developed a variety of marketing, merchandising, and advertising materials for California producers and retailers under the Buy Fresh Buy Local brand name. CAFF has developed a variety of marketing, merchandising, and advertising materials for California producers and retailers under the Buy Fresh Buy Local brand name. CAFF's producer members are listed on the Buy Fresh Buy Local website and included in the Buy Fresh Buy Local Eater's Guide.
The degree to which information about product origin is retained to point of sale varies from supplier to supplier, but there are several actions that Co-op Partners Warehouse takes to increase the visibility of its suppliers and enhance producer-consumer relationships. They include an online list of producer profiles on the Co-op Partners Warehouse website; a drop-ship program which shortens food supply chains, thereby creating opportunities for producers and buyers to communicate directly about production practices and product origin; and finally, The Wedge Community Co-op's 2007 acquisition of the Gardens of Eagan Farm (an organic vegetable farm located outside Minneapolis/St. Paul), which has created additional learning opportunities for consumers through its 501(c)(3) nonprofit, The Organic Field School.
Growers wash, grade, and pack their produce on-farm and then either deliver it to the Organic Valley distribution facility or have it picked up for a small fee. Because it works largely with Amish growers who have limited cold storage and transportation options, Organic Valley has found it necessary to pick up perishable product shortly after it is harvested and select crops that require less stringent temperature control. As a result, the co-op plans to develop a centralized grading and packing facility with forced air and hydrocooling to improve product grading, increase pack-size options, and extend the shelf life of its products. Organic Valley also has a freight logistics operation, Organic

Logistics, which coordinates its regional and national hauling.

Organic Valley produce is sold under the Organic Valley label. Individual farms are not identified, but the state of origin is coded on each case and Organic Valley is pursuing the placement of Global Trade Item Number (GTIN) bar codes on all of its cases. Organic Valley also regularly provides its buyers with sales sheets and point-of-sale merchandising materials. 


\begin{tabular}{|c|c|c|c|}
\hline Pricing & $\begin{array}{l}\text { Under CAFF management, Growers } \\
\text { Collaborative farmers set their own prices and } \\
\text { buyers meet them without resistance. As a } \\
\text { representative from CAFF explained, the } \\
\text { premium a buyer pays for local food is typically } \\
\text { minimal relative to the marketing opportunities } \\
\text { they gain by being able to advertise to their } \\
\text { customers that they source locally. }\end{array}$ & $\begin{array}{l}\text { Co-op Partners negotiates prices directly with } \\
\text { local growers. Its markup ranges from } 16 \% \text { to } \\
25 \% \text {, depending on product perishability. Prices } \\
\text { are set in advance or determined as needed. }\end{array}$ & $\begin{array}{l}\text { Organic Valley's growers are paid a base price } \\
\text { biweekly based on the products and volume } \\
\text { they supply. Growers also receive a "pooling } \\
\text { bonus" at the end of the season - the } \\
\text { difference between the revenues and base } \\
\text { price of each crop minus freight and } \\
\text { commission costs. Organic Valley sees room for } \\
\text { improvement in identifying the cost of } \\
\text { production of each of its produce products. It } \\
\text { has found that many of its growers have } \\
\text { insufficient knowledge of their input and labor } \\
\text { costs; if it could obtain this data, Organic Valley } \\
\text { would be more able to advocate for } \\
\text { sustainable price returns and cut production of } \\
\text { unprofitable crops. To help bridge this } \\
\text { knowledge gap, Organic Valley offers cost-of- } \\
\text { production workshops and workbooks for its } \\
\text { growers. }\end{array}$ \\
\hline
\end{tabular}

